\title{
FENOMENA TINDAKAN MAIN HAKIM SENDIRI DALAM HUKUM NEGARA DAN HUKUM ISLAM
}

\author{
Asrizal Saiin \\ Universitas Muhammadiyah Riau \\ asrizalsaiin@gmail.com
}

\author{
Ahmad Iffan \\ Mahasiswa Pascasarjana Fakultas Hukum Universitas Gadjah Mada \\ a.jurist08@gmail.com
}

\begin{abstract}
ABSTRAK
Perbuatan main hakim sendiri tidak hanya merugikan negara tetapi dapat meruntuhkan moral masyarakat. Tindakan main hakim sendiri telah diatur di dalam agama Islam dan Undang-Undang Dasar Negara Indonesia. Tindakan main hakim sendiri belum diatur secara khusus dalam peraturan perundang-undangan pidana terkhususnya Kitab Undang-undang Hukum Pidana (KUHP). Akan tetapi, bukan berarti KUHP tidak dapat diterapkan sama sekali jika terjadi perbuatan main hakim sendiri, Main hakim sendiri selain merupakan perbuatan melawan hukum juga bertentangan dengan ajaran agama Islam. Agama Islam mengajarkan untuk melakukan tabayyun (memintai keterangan) terlebih dahulu. Berbagai dalil Alquran menjelaskan bagaimana tindakan main hakim sendiri adalah perbuatan sangat keji dan dilarang oleh norma agama. Argumentasi terkait tindakan main hakim sendiri didasari oleh pemikiran masyarakat yang menganggap bahwa perbuatan berdua-duaan di suatu tempat antara dua orang yang berbeda jenis kelamin yang belum menikah merupakan perbuatan yang melanggar norma yang tidak sesuai dengan ajaran agama, kesusilaan dan kesopanan. Walaupun demikian, cara penyelesaian masalah tersebut adalah tetap mengedepankan nilai-nilai moral yang menjunjung tinggi harkat dan martabat manusia.
\end{abstract}

Abstract : The vigilante act does not only harm the nation but also damages people's morale. It is regulated in Islam and the Indonesian Constitution. It has not been specifically regulated in criminal legislation specifically in the Criminal Code (KUHP). However, it does not mean that the Criminal Code cannot be applied at all if there is a vigilante act. It does not only oppose the law but also it is contrary to the Islamic teaching. Islam teaches to confirm first. Various Quranic Dalil explain how vigilante acts are very despicable and prohibited by religious norms. The argument related to vigilante act is based on the public's thought that the act of two-person somewhere between two people of different sexes is an act that violates the norm. It is not suitable with religious teaching, decency and politeness. Therefore, the way to solve the problem is to keep emphasizing moral values that uphold human dignity.

Kata Kunci: Sosiologi bukum, Hukum Negara, Hukum Islam.

\section{Pendahuluan}

Tindakan main hakim sendiri selalu menjadi pemberitaan hangat dimasyarakat Indonesia. Terlebih lagi terhadap kasus perzinahan, tindakan tersebut bahkan berujung pada tindakan penganiayaan hingga pembunuhan terhadap korban yang dilakukan oleh beberapa oknum masyarakat. Adanya tindakan main hakim sendiri sebagai sebuah peristiwa menyedihkan mengingat adanya ketentuan aturan hukum pada Pasal 1 ayat (3) Undang-Undang Dasar Negara Republik Indonesia (UUD NRI) yang menyatakan Indonesia adalah negara hukum.
Dengan demikian, seharusnya hukumlah yang menjadi penyelesaian resmi yang sah dari berbagai konflik yang timbul dalam masyarakat. Selain itu, tindakan main hakim sendiri juga bertentangan dengan pasal Hak Asasi Manusia (HAM) yang dijamin dalam UUD NRI. Pasal 28 G ayat (2) UUD NRI menyatakan bahwa setiap orang berhak bebas dari penyiksaan atau perlakuan yang merendahkan derajat martabat manusia.

Islam tidak hanya sebagai payung hukum dalam beribadah kepada Allah swt, tetapi juga sebagai struktur norma masyarakat yang menegakkan norma-norma sosial, 
aturan-aturan, peningkatan spiritual dan media hubungan dengan tuhannya. ${ }^{1}$ Main hakim sendiri selain merupakan perbuatan melawan hukum juga bertentangan dengan ajaran agama Islam. Main hakim sendiri oleh masyarakat merupakan tindakan tercela dan tidak dibenarkan oleh agama Islam. Hukum Islam menjadi kesadaran tertinggi dalam melakukan tindakan yang diatur maupun tidak diatur oleh hukum positif.

Main hakim sendiri dapat memberikan dampak psikologis bagi korban. ${ }^{2}$ Korban dari tindakan ini dalam jangka panjang dapat mengalami depresi dan Post Traumatic Stress Disorder (PTSD). ${ }^{3}$ Untuk memulihkan kondisi korban tersebut diperlukan proses rehabilitasi yang tidak sebentar. ${ }^{4}$ Hal itu bahkan juga tidak mampu menyembuhkan total rasa trauma dalam diri korban. ${ }^{5}$ Melihat pada berbagai dampak dari main hakim sendiri, tergambar bahwa tindakan ini sebenarnya sangat merugikan bagi korban namun di sisi lain dianggap kelaziman dalam masyarakat.

Perbuatan main hakim sendiri yang dilakukan oleh masyarakat terhadap kasus perzinahan pada dasarnya dilarang oleh undang-undang, karena yang berwenang memproses dan menyelesaikan permasalahan hukum yang terjadi di masyarakat adalah aparat penegak hukum. Faktanya tindakan main hakim sendiri sering dan lazim di berbagai daerah di Indonesia. Tempat keramaian seringkali menjadi tempat ditemukan tindakan main hakim sendiri oleh masyarakat. Sering terdengar berita apabila ada sepasang laki-laki dan perempuan yang melakukan perzinahan, mereka langsung dikeroyok hingga luka-luka karena dihakimi massa tanpa dimintai keterangan terlebih dahulu. Tragisnya tidak sedikit yang kehilangan nyawa akibat amukan massa yang

1 Imam Sukardi, et al., 2003, Pilar Islam Bagi Pluralisme Modern, PT Tiga Serangkai Pustaka Mandiri, Solo, hlm.26

2 Lihat, https://tirto.id/dampak-psikispersekusi-penelanjangan-cz8q, diakses pada tanggal 20

Maret 2018 pukul. 18:00 WIB.

${ }^{3}$ Ibid.

${ }^{4}$ Ibid.

${ }^{5}$ Ibid. melakukan pengeroyokan. Padahal, agama Islam mengajarkan untuk melakukan tabayyun (memintai keterangan) terlebih dahulu. Berdasarkan kerisauan dari fenomena tindakan main hakim sendiri yang sering terjadi di Indonesia sekarang ini, maka penulis tertarik mengkajinya.

Metode penelitian dalam tulisan ini adalah penelitian kepustakaan (library reserch) atau studi dokumentasi. Penelitian kepustakaan dilakukan untuk mendapatkan konsepsi kebijakan teori atau doktrin, dan pemikiran konseptual serta penelitian pendahulu yang berkaitan dengan objek telaah penelitian ini yang dapat berupa literatur karya tulis ilmiah dan lain sebagainya. Riset pustaka yang membatasi kegiatan hanya kepada bahan-bahan koleksi perpustakaan saja sedangkan data-data wawancara dipergunakan untuk mengkonfirmasi dan memperjelas (klarifikasi) data-data yang diperoleh dari pustaka tersebut. ${ }^{6}$

\section{Hasil dan Diskusi}

Sosiolog terkemuka, Emile Durkheim dalam bukunya yang berjudul The Sociology of Law menyatakan bahwa tindakan individu dipengaruhi oleh fakta sosial (social fact) dalam masyarakat. ${ }^{7}$ Fakta sosial ini menggambarkan bagaimana nilai, budaya dan norma dalam masyarakat mampu menggerakan tindakan individu. ${ }^{8}$ Dengan demikian, memang dalam menganalisis suatu tindakan individu, Emile Durkheim melihatnya dalam aspek yang makro yakni masyarakat sebagai penggerak individu atau yang mempengaruhi individu. Dari analisis data tersebut, maka fenomena tindakan main hakim sendiri dapat dianalisis berdasarkan hukum negara dan hukum Islam.

\section{Perspektif Hukum Negara}

Hukum nagara adalah perwujudan nilai-nilai dan mengandung arti bahwa kehadirannya untuk melindungi dan

6 Mestetika Zed, Metode Penelitian Kepustakaan, (Jakarta: Yayasan Obor Indonesia, 2004), hlm. 2

7 A. Javier Trevino, 2008, The Sociology of Law, St. Martins Press, New York, hlm. 234.

${ }^{8}$ Ibid.

${ }^{9}$ Ibid., hlm. 235. 
memajukan nilai-nilai yang dijunjung tinggi oleh masyarakat di negara tersebut. Terdapat tuntutan terhadap hukum agar dapat memberikan keadilan dan apakah hukum itu sendiri dapat mewujudkann keadilan. Eksistensi dan kemampuan hukum lalu diukur seberapa jauh ia telah mewujudkan keadilan yang dicita-citakan masyarakat yang kemudian nilai-nilai keadilan telah menjadi dasar unntuk mensahkan kehadiran dan bekerjanya hukum. $^{10}$ Perwujudan dari pencarian keadilan dapat dilakukan dengan penegakan hukum sehingga dapat dicapai keadilan yang dicita-citakan.

Tindakan main hakim sendiri selalu berjalan dengan pelanggaran hak-hak orang lain, dan oleh karena itu tidak diperbolehkan perbuatan ini menunjukan bahwa adanya indikasi rendahnya kesadaran masyarakat terhadap hukum negara. Tindakan main hakim sendiri sudah diatur di dalam Pasal 1 ayat (3) UUD NRI. Hal ini ditarik kesimpulan bahwa tindakan main hakim sendiri digolongkan kepada perbuatan yang melanggar hak asasi manusia.

Sekalipun korban main hakim sendiri merupakan pelaku tindak pidana, pelaku masih memiliki hak asasi yang harus dihormati dan diberikan kepada setiap individu. Adapun hak-hak yang dilanggar menurut ketentuan hukum positif yang ada adalah sebagai berikut:

a. Pasal 28D ayat (1) UUD NRI menyatakan bahwa "Setiap orang berhak atas pengakuan, jaminan, perlindungan, dan kepastian hukum yang adil serta perlakuan yang sama di hadapan hukum." Hak yang sebagaimana disebutkan pada Pasal tersebut merupakan hak yang fundamental atau mendasar yang pemenuhan akan hak tersebut merupakan tugas dari negara sebagaimana yang disebutkan pada Pasal 28I ayat (4) UUD NRI.

b. Pasal 4 Undang-Undang Nomor 39 Tahun 1999 Tentang Hak Asasi

10 Satjipto Rahardjo, 2010, Sosiologi Hukum (Perkembangan Metode dan Piliban Masalab), Genta Publishing, Yogyakarta, hlm. 66-67
Manusia yang menyatakan "Hak untuk hidup, hak untuk tidak disiksa, hak kebebasan pribadi, pikiran dan hati nurani, hak beragama, hak untuk tidak diperbudak, hak untuk diakui sebagai pribadi dan persamaan di hadapan hukum, dan hak untuk tidak dituntut atas dasar hukum yang berlaku surut adalah hak asasi manusia yang tidak dapat dikurangi dalam keadaan apapun dan oleh siapapun".

Tindakan main hakim sendiri belum diatur secara khusus dalam peraturan perundang-undangan pidana terkhususnya Kitab Undang-Undang Hukum Pidana (KUHP). Akan tetapi, bukan berarti KUHP tidak dapat diterapkan sama sekali jika terjadi perbuatan main hakim sendiri. Dalam hal terjadinya tindakan main hakim sendiri, bagi korban tindakan tersebut dapat melaporkan kepada pihak yang berwenang antara lain atas dasar ketentuan-ketentuan berikut:

1) Pasal 351 KUHP tentang

Penganiayaan

a. Penganiayaan diancam dengan pidana penjara paling lama dua tahun delapan bulan atau pidana denda paling banyak empat ribu lima ratus rupiah,

b. Jika perbuatan mengakibatkan luka-luka berat, yang bersalah diancam dengan pidana penjara paling lama lima tahun.

c. Jika mengakibatkan mati, diancam dengan pidana penjara paling lama tujuh tahun.

Penjelasan Pasal 351 KUHP menyatakan bahwa penganiayaan diartikan sebagai perbuatan dengan sengaja yang menimbulkan rasa tidak enak, rasa sakit atau luka. Hal ini dapat diancamkan atas tindakan main hakim sendiri yang dilakukan terhadap orang yang mengakibatkan luka atau cidera. $^{11}$

11 Kartika Febriyanti, Pidana Bagi Pelaku Main Hakim Sendiri, http://www.hukumonline. Com/ klinikdetail/lt4ec445fc806be/pidana-bagi-pelakumain-hakim-sendiri diakses pada tanggal 30 Maret 2018 pukul 16:00 WIB. 
2) Pasal 170 KUHP tentang Kekerasan

a. Barang siapa dengan terangterangan dan dengan tenaga bersama menggunakan kekerasan terhadap orang atau barang, diancam dengan pidana penjara paling lama lima tahun enam bulan.

b. Yang bersalah diancam:

a) dengan pidana penjara paling lama tujuh tahun, jika ia dengan sengaja menghancurkan barang atau jika kekerasan yang digunakan mengakibatkan luka-luka.

b) dengan pidana penjara paling lama sembilan tahun, jika kekerasan mengakibatkan luka berat;

c) dengan pidana penjara paling lama dua belas tahun, jika kekerasan mengakibatkan maut.

Dalam penjelasan Pasal 170 KUHP menyatakan bahwa kekerasan terhadap orang maupun barang yang dilakukan secara bersama-sama, yang dilakukan di muka umum seperti perusakan terhadap barang, penganiayaan terhadap orang atau hewan, melemparkan batu kepada orang atau rumah, atau membuang-buang barang sehingga berserakan. Hal ini dapat diancamkan atas tindakan main hakim sendiri yang dilakukan di depan umum. ${ }^{12}$ Untuk menjamin dan memastikan tegaknya hukum itu, apabila diperlukan, aparatur penegak hukum itu diperkenankan untuk menggunakan daya paksa. $^{13}$

Sebaiknya hukum dalam hal ini bekerja untuk mengubah perilaku masyarakat, yang mana pada awalnya perilaku tersebut dinilai sebagai perilaku yang tidak menyimpang, namun selanjutnya disebut sebagai perilaku menyimpang atau suatu pelanggaran. Untuk melakukan hal tersebut, butuh waktu yang tidak sebentar, dimana

\footnotetext{
${ }^{12}$ Ibid.

13 Satjipto Rahardjo, 1979, Hukum dan
} Perubahan Sosial, , Alumni, Bandung, hlm. 123-124. perlu adanya pengertian dan sosialisasi terhadap masyarakat.

\section{Perspektif Hukum Islam}

Al-Quran menjelaskan secara tegas larangan melakukan perzinahan dan tindakan menghakimi perbuatan tersebut, seperti firman Allah swt:

$$
\text { و لا تقربو ا الزنى انه كان فحشة وساء سبيلا }
$$

\section{Dan janganlah kamu mendekati zina; Sesunggubnya zina itu adalab suatu perbuatan yang keji dan suatu jalan yang buruk. (Al Isro': 32).}

Dalil lain memperkuat terkait konsekuensi terhadap perzinahan adalah:

الزانية والزانى فاجلدوا كل وحد منهما مائة جلدة ولا

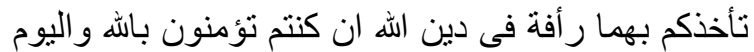

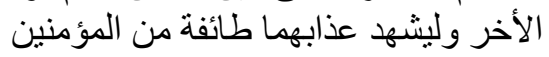

Perempuan yang berzina dan laki-laki yang berzina, maka deralah tiap-tiap seorang dari keduanya seratus dali dera, dan janganlah belas kasiban kepada keduanya mencegah kamu untuk (menjalankan) agama Allah, jika kamu beriman kepada Allah, dan hari akbirat, dan hendaklah (pelaksanaan) bukuman mereka disaksikan oleh sekumpulan orangorang yang beriman. (An-nur: 2).

Ayat-ayat tersebut berpotensi dijadikan alasan bagi pelaku main hakim sendiri terhadap sepasang laki-laki dan perempuan yang berduaan di suatu tempat. Selain itu, dorongan untuk melakukan amar ma'ruf nahi mungkar (menegakkan kebenaran dan memerangi kemaksiatan) menjadi landasan sebagian masyarakat yang mengambil pilihan tindakan main hakim sendiri jika melihat ada sepasang laki-laki dan perempuan berada disuatu tempat berdua saja. Hal ini sebagaimana disebutkan dalam Surat Ali Imran ayat 104 yang menyatakan sebagai berikut : 


$$
\begin{aligned}
& \text { ولتكن منكم امة يدعون الى الخير ويأمرون بالمعروف المن } \\
& \text { وينهون عن المنكر واولئك هم المفلحون الثير }
\end{aligned}
$$

Dan hendaklah ada di antara kamu segolongan umat yang menyeru kepada kebajikan, menyurub kepada yang ma'ruf dan mencegah dari yang munkar; merekalah orang-orang yang beruntung. (Ali Imran: 104).

Dalam analisa penulis, ayat di atas tidak dapat dijadikan dalil untuk pembenaran tindakan main hakim sendiri. Tindakan yang diambil oleh pelaku untuk main hakim sendiri sebenarnya tidak dibenarkan oleh Agama Islam. Agama Islam melarang melakukan perbuatan penganiayaan terhadap sesama makhluk hidup terutama sesama manusia yang merupakan makhluk ciptaan Allah yang lebih sempurna dari ciptaan lainnya. Sebagaimana Allah swt menyebutkan dalam al-Quran:

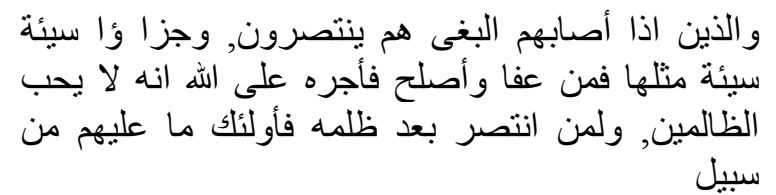

Dan (bagi) orang-orang yang apabila mereka diperlakukan dengan zalim, mereka membela diri. Dan balasan suatu kejahatan adalah kejahatan yang setimpal, tetapi barangsiapa memaafkan dan berbuat baik (kepada orang yang berbuat jahat) maka pahalanya dari Allah. Sungguh, Dia tidak menyukai orang-orang zalim. Tetapi orang-orang yang membela diri setelah diralimi, tidak ada alasan untuk menyalabkan mereka. (QS.

Ash-Shuraa ayat 39-41)

Keadilan dalam Islam tidak hanya sekedar aturan dan isi dari dalil dalil alqur"an tetapi berhubungan erat dengan ketakwaan seorang muslim kepada tuhannya sebagaimana yang dikutip dari surat Al-Maidah ayat $8,{ }^{14}$ dan berbuat adil adalah salah satu jalan menuju takwa.

14 Rizal Ariffin Hairul Nizam Ismail, "Konsep Keadilan dalam Teori Kecerdasan Pelbagai Menurut Perspektif Islam”, DP, Vol. 2, 2007, hlm 66-73.
Main hakim sendiri oleh masyarakat merupakan tindakan tercela dan tidak dibenarkan oleh berbagai agama, bahkan seluruh agama resmi di Indonesia tidak membenarkan untuk melakukan main hakim sendiri terhadap pelaku yang melakukan perbuatan perzinahan atau tindakan asusila tersebut. Hukum Islam menjadi kesadaran tertinggi dalam melakukan tindakan yang diatur maupun tidak diatur oleh hukum positif. Ayat pada Surat Annur tidak membolehkan melakukan penghukuman langsung tanpa melewati pengadilan (hukum yang berlaku), hukuman terhadap pelaku dilakukan setelah melewati proses peradilan yang adil dan diputuskan oleh hakim yang adil. Islam mengajarkan untuk selalu adil dan berprilaku adil berdasarkan dalil-dalil hukum yang jelas.

Pelaku perzinahan tidak berhak diadili secara sepihak sebelum ada keputusan hukum yang mengikat, Islam adalah agama rahmatal lilalamin, artinya setiap tindakan harus membawa rahmat terhadap seluruh alam, islam tidak hanya mengajarkan kepada kadilan secara teori tetapi juga pada tataran praktik termasuk wajib mematuhi hukum yang berlaku di suatu negara. Berbagai dalil al-Quran menjelaskan bagaimana tindakan main hakim sendiri adalah perbuatan sangat keji dan dilarang oleh norma agama. Sebagaimana firman Allah swt di bawah ini:

$$
\begin{aligned}
& \text { ان الله بأمر بالعدل والاحسن وايتاى ذى القربيى وينهى }
\end{aligned}
$$

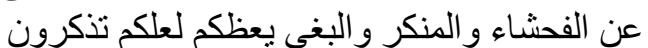

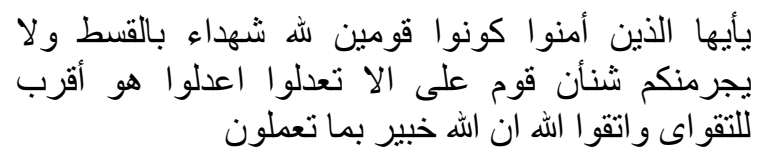


Hai orang-orang beriman! Jadilah kamu penegak keadilan, sebagai saksi-saksi karena Allab, dan janganlah kebencian orang kepadamu membuat kamu berlaku tidak adil. Berlakulah adil. Itu lebih dekat kepada takwa. Dan bertakwalah kepada Allah. Allah tahu benar apa yang kamu kerjakan. (Q.s. AlMaidah [5]: 8).

Ayat-ayat di atas menunjukan adanya perintah untuk tidak melakukan tindakan main hakim sendiri. Meskipun pada kenyataannya bahwa setiap tindakan manusia pasti telah berbuat salah, konskuensi yang diajarkan Allah Swt, bahwa mencintai dan memandang manusia sebagai makhluk yang memiliki harkat dan martabat. Cara penyelesaian masalah tersebut adalah tetap mengedepankan nilai-nilai moral yang menjunjung tinggi harkat dan martabat manusia.

Menegakkan keadilan dalam membawa keberkahan terhadap masyarakat sebagaimana teori ikhsan yaitu dengan berperilaku adil, sabar dan ikhlas dalam bermasyarakat maka akan membawa kepada kedamaian dan kearifan, dari ayat di atas dapat diambil empat garis hukum yang berisi perintah dan larangan kepada manusia yaitu:

1. Perintah kepada orang-orang yang beriman supaya menjadi manusia yang lurus (adil), dari perkataan alqist karena Allah. Garis hukum ini mengandung makna bahwa setiap perbuatan yang adil dilakukan oleh manusia karena keikhlasannya semata-mata kepada Allah, bukan karena hal lain.

2. Perintah kepada orang-orang yang beriman supya menjadi saksi yang adil, artinya dalam kesaksiannya itu, ia tidak memihak kepada siapapun, kecuali kepada kebenaran.

3. Larangan kepada orang-orang yang beriman untuk bersikap tidak adil, karena motivasi emosional atau sentimen yang negatif (benci) kepada sutu kelompok manusia atau seorang tertentu. Ayat ini dapat ditafsirkan pula, manusia dilarang bersikap tidak adil karena motivasi emosioal yang positif, misalnya sayang atau belas kasihan kepada suatu kelompok atau seseorang tertentu. Ringkasnya, setiap orang yang beriman wajib menjadi saksi yang adil tanpa dipengaruhi oleh sesuatu perasaan apapun, kecuali kebenaran.

4. Perintah kepada orang-orang yang beriman supaya bersikap adil, karena adil lebih dekat dengan takwa.

\section{Faktor Melakukan Tindakan Main Hakim Sendiri}

Masyarakat Indonesia merupakan masyarakat multikultural yang dinamis, sehingga adanya perubahan sosial merupakan fenomena tak terhindarkan (unavoidable phenomena) dalam masyarakat itu sendiri. Sebagaimana pandangan yang dikemukakan oleh Heraklitos, bahwa hidup dimaknai sebagai perubahan "Panta rhei kai ouden menei" yang artinya "Tiada yang tetap, semua mengalir, semuanya berubah". ${ }^{15}$ Perubahan yang timbul dalam masyarakat sangat beragam dan memiliki sebabnya masingmasing yang mengarah pada dua keadaan, yakni perubahan ke arah yang lebih baik (progress) dan perubahan kearah yang lebih buruk (regress).

Perubahan sosial yang ada dalam masyarakat juga dapat terjadi pada nilai dan norma sosial maupun pola perilaku organisasi masyarakat. ${ }^{16}$ Tindakan main hakim sendiri dijadikan sebagai adanya perubahan nilai dan norma sosial yang ada pada masyarakat. Tindakan main hakim sendiri adalah cerminan dari nilai dan norma yang berkembang dalam masyarakat. Pandangan bahwa laki-laki dan perempuan yang ada dalam satu kamar merupakan tindakan yang tidak bermoral, melanggar kaedah kesopanan

15 H.A Saefudin, 2005, "Teori Konflik dan Perubahan Sosial: Sebuah Analisais Kritis", Mediator, Vol. 6, No. 1 Juni 2005, hlm. 75.

16 Sumartono, "Dinamika Perubahan Sosial dalam Teori Konflik", Jurnal Universitas Ekasakti, hlm. 2 
dan kesusilaan tersebut merubah pola perilaku organisasi masyarakat, dalam konteks ini diinisiasi oleh tokoh masyarakat, dengan langsung melakukan tindakan amoral yang tidak sesuai dengan prikemanusian dan prikeadilan. ${ }^{17}$

Hal ini menjadi bukti bahwa dalam lini masyarakat terjadi perubahan sosial yang bersifat regress. Masyarakat memilih konflik bahkan cenderung mengadili untuk menyelesaikan sebuah permasalahan. Hal tersebut sejalan dengan pandangan Ralf Dahrendorf dalam teori konflik yang berpangkal pada anggapan dasar bahwa: ${ }^{18}$

1. Setiap masyarakat senantiasa berada pada proses perubahan yang tidak pernah berakhir, atau dengan perkataan lain, perubahan sosial merupakan gejala yang melekat di dalam setiap masyarakat.

2. Setiap masyarakat mengandung konflik di dalam dirinya, atau dengan perkataan lain, konflik adalah gejala yang melekat di dalam masyarakat.

3. Setiap unsur di dalam suatu masyarakat memberikan sumbangan bagi terjadinya disintegrasi dan perubahan sosoal.

4. Setiap masyarakat terintegrasi di atas penguasaan atau dominasi oleh sejumlah orang atas sejumlah orang yang lain.

Tindakan main hakim sendiri dalam sisi yang lain dapat dipandang sebagai bentuk penyelesaian yang tidak terlepas dari tatanan sosia (social order) dari masyarakat itu sendiri. Teori konflik yang dipadukan pada masalah sosial, Simmel menyatakan bahwa "viewing conflict as a normal part of the social order, Simmel regards legal relations within the context of superordination-subordiation interactions as being

17 Muhammad Agung Riyadi, Kasus Penelanjangan di Tangerang, Perlu Kehati-hatian Rumuskan Pasal Kesusilaan, http://www.gresnews.com/berita/hukum/901511kasus-penelanjangan-di-tangerang-perlu-kehati-hatianrumuskan-pasal-kesusilaan/0/, diakses pada 2 Maret 2018 pukul 18:00 WIB.

${ }^{18}$ Johnson, Doyle Paul, dalam Sumartono, Loc. reciprocal, not just oppressive". ${ }^{19}$ Tindakan main hakim sendiri dilakukan oleh masyarakat sebagai bentuk tanggapan masyarakat terhadap perbuatan-perbuatan atau gejala yang timbul di masyarakat yang dipandang sebagai perbuatan yang merugikan masyarakat atau membahayakan masyarakat luas, akan tetapi undang-undang secara formal belum mengaturnya.

Fenomena tindakan main hakim sendiri muncul akibat kekecewaan terhadap hukum formal atau aparat penegak hukum. Masyarakat juga menganggap bahwa apabila ada tindakan asusila dilingkungan sekitar tempat tinggal mereka, akan menjadi aib dan kotor, hal itu disebabkan karena tingkat religius dan nilai-nilai kearifan lokal masyarakat masih kental.

Menurut Donald Black sebagaimana dikemukakan Zainuddin Ali, ketika pengendalian sosial melalui upaya hukum tidak jalan, maka bentuk lain dari pengendalian sosial secara otomatis akan muncul. Tindakan yang dilakukan oleh individu dan kelompok yang dari perspektif hukum dapat digolongkan sebagai tindakan main hakim sendiri, pada hakikatnya merupakan wujud pengendalian sosial yang dilakukan masyarakat. ${ }^{20} \quad$ Keterbatasan $^{2}$ kemampuan hukum pidana dalam penanggulangan kejahatan menjadikan efektivitas hukum pidana tidak dapat diukur secara akurat. Hukum hanya merupakan salah satu sarana kontrol sosial. Kebiasaan, keyakinan agama, dukungan, dan pencelaan dari pendapat umum dan dari kelompokkelompok interest serta pengaruh dari pendapat umum merupakan sarana-sarana yang lebih efisien dalam mengatur tingkah laku manusia daripada sanksi hukum. ${ }^{21}$

Tindakan masyarakat yang memilih untuk menindak perbuatan perzinahan dilingkungannya dijadikan sebagai bentuk kontrol sosial. Kontrol tersebut lahir dengan

19 A. Javier Treviño, The Sociology of Law, hlm. 350.

20 Zainuddin Ali, 2007, Sosiologi Hukum, Sinar Grafika, Jakarta, hlm. 60.

21 Is. Heru Permana, 2007, Politik Kriminal, Kanisius, Yogyakarta. hlm. 45. 
pandangan bahwa manusia sebagai mahkluk yang bermoral yang tinggal dan berdiam dalam lingkungan yang beradab. Sehingga kelompok masyrakat yang berdiam dalam lingkungan tersebut wajib menjaga ketentraman didalam lingkungannya. Masyarakat itu sendiri lebih tunduk dan meyakini bahwa nilai-nilai leluhur yang tumbuh dan berkembang dijadikan sebagai pedoman hidup dan penyelesaian yang sederhana merupakan proses untuk menyelesaikan perkara apabila ada tindakan yang tidak sesuai dengan nilai-nilai kearifan masyarakat. Penerapan sanksi dapat dilakukan melalui kesepakatan bersama masyarakat ataupun keputusan dari pimpinan masyarakat.

Satjipto Rahardjo mengajarkan bahwa hukum adalah tatanan (order) yang utuh dan luas, yaitu tatanan transendental, tatanan sosial, dan tatanan politik. Hukum positif adalah tatanan politik yang dalam tatanan utuh tersebut hanya menempati satu sudut kecil saja. Berdasarkan teori maka diterapkannya tindakan main hakim sendiri oleh kelompok masyarakat dilatari karena perilaku perzinahan yang dilakukan oleh dua orang yang berbeda jenis kelamin dan tanpa ikatan status perkawinan yang sedang berduaan di suatu tempat.

Argumentasi terkait tindakan main hakim sendiri didasari oleh pemikiran masyarakat yang menganggap bahwa perbuatan berdua-duaan di suatu tempat antara dua orang yang berbeda jenis kelamin yang belum menikah merupakan perbuatan yang melanggar norma yang tidak sesuai dengan ajaran agama, kesusilaan dan kesopanan. Kelompok masyarakat kemudian berupaya dengan jalannya sendiri untuk melakukan tindakan dengan cara melakukan persekusi (main hakim sendiri) seperti diarak dan dipertontonkan di depan umum.

Pengaturan mengenai tindakan asusila terhadap para perlaku perzinahan yang berdua-duaan di suatu tempat tanpa ikatan perkawinan belum diatur dalam hukum positif. Aparat penegakan hukum terkadang enggan untuk bertindak sebab dalam kacamata mereka perbuatan tersebut bukan perbuatan yang melanggar hukum pidana. Kelompok masyarakat sendiri merasa kecewa sebab tidak ada sanksi tegas yang dapat diambil sehingga jalan yang diambil adalah menghakimi sendiri para pelaku, baik dengan cara diarak atau dipermalukan didepan umum. Kelompok masyarakat pun merasa tanpa sanksi yang tegas, para pelaku akan mengulangi perbuatannya dan apabila tidak diterapkan sanksi maka akan terjadi kegoncangan sosial dalam masyarakat yaitu menjadi aib di lingkungan masyarakat. Tindakan main hakim sendiri dapat dikatakan sebagai tindakan negatif dari luapan emosi dan kekecewaan masyarakat. Apabila memandang hukum sebagai suatu tatanan yang luas dan utuh seperti yang diungkap oleh Satjipto Rahardjo, maka kaedah hukum tidak sebatas dalam hukum positif saja.

\section{Kesimpulan}

Tindakan main hakim sendiri dalam sistem kehidupan masyarakat di Indonesia pada umumnya merupakan suatu tindakan yang sangat tidak manusiawi dan menelanjangi martabat kemanusiaan. Tentunya nilai-nilai HAM merupakan hak yang sangat dijunjung tinggi oleh bangsabangsa yang beradab di seluruh dunia khususnya Indonesia. Menyoal dari sisi nilainilai HAM, tentunya kecaman dari masyarakat luas terhadap pelaku main hakim sendiri merupakan hal yang wajar mengingat penilaian masyarakat secara umum dan negara, tindakan main hakim sendiri sama sekali tidak diperbolehkan oleh hukum yang berlaku secara positif khususnya di Indonesia.

Menelaah dari sudut pandang Islam, pelaku yang melakukan perbuatan perzinahan sangat berkaitan dengan nilai-nilai keislaman yang dijunjung tinggi dalam suatu masyarakat Islam yang ada dalam budaya masyarakat Islam itu sendiri. Norma keislaman sebagaimana diketahui merupakan ajaran Islam itu sendiri yang ditujukan kepada sikap lahir pelakunya yang konkrit demi penyempurnaan atau ketertiban masyarakat dan bertujuan menciptakan perdamaian, tata tertib atau membuat "sedap" lalu lintas antar 
manusia yang bersifat lahiriah. Norma keislaman pada dasarnya adalah kepantasan, kebiasaan, kepatutan yang berlaku dalam masyarakat. ${ }^{22}$

Islam membebani manusia dengan kewajiban untuk berprilaku sebagaimana yang ada di lingkungan masyarakat. Kekuasaan masyarakat secara tidak resmilah yang mengancam dengan sanksi jika ajaran Islam itu dilanggar. Kaedah Islam adalah kaedah yang paling benar dan paling asli, juga terdapat di dalam sanubari manusia sendiri karena manusia makhluk bermoral, tanpa melihat kebangsaan atau masyarakat, dengan kata lain tidak mengindahkan norma susila berarti asusila. $^{23}$ Jika dikaitkan dengan tindakan main hakim sendiri yang terjadi dari sudut pandang warga masyarakat yang melakukan main hakim sendiri, tentunya masyarakat menginginkan terciptanya lingkungan yang kondusif tanpa adanya keresahan diakibatkan oleh tindakan remaja yang berduaan di suatu tempat sehingga menggunakan tindakan main hakim sendiri sebagai alat demi mencapai tujuan tersebut. Tindakan individu yang berdua-duaan di suatu tempat tanpa adanya ikatan perkawinan yang sah dianggap warga sebagai pelanggaran norma kesusilaan.]

\section{DAFTAR RUJUKAN}

\section{A. Buku}

Arief, Barda Nawawi, 2002, Kebijakan Hukum Pidana, PT. Citra Aditya Bakti, Bandung.

Hiariej, Eddy O.S, 2015, Prinsip-Prinsip Hukum Pidana Edisi Revisi, Cahaya Atma Pustaka, Yogyakarta.

Hamzah, Andi, 1986, Kamus Hukum, Ghalia Indonesia, Jakarta.

Imam Sukardi, et al., 2003, Pilar Islam Bagi Pluralisme Modern, PT Tiga Serangkai Pustaka Mandiri, Solo.

22 Sudikno Mertokusumo, 1985, Mengenal Hukum (Suatu Pengantar), Liberty, Yogyakarta, hlm. 8.

${ }^{23}$ R. Soeroso, Pengantar Ilmu Hukum, hlm. 216.
Mertokusumo, Sudikno, 1985, Mengenal Hukum (Suatu Pengantar), Liberty, Yogyakarta.

Is. Heru Permana, 2007, Politik Kriminal, Kanisius, Yogyakarta.

Lawrence M. Friedman dalam bukunya The Legal System: A Sociology Science Perspective, dalam Soerjono Soekanto, et. all., 1986, Kriminologi Suatu Pengantar, Ghalia Indonesia, Jakarta,

Permana, Is. Heru 2007, Politik Kriminal, Kanisius, Yogyakarta.

R. Soeroso, 1992, Pengantar Ilmu Hukum, Sinar Grafika, Jakarta.

Rahardjo, Satjipto, 1979, Hukum dan Perubahan Sosial, , Alumni, Bandung.

Rahardjo, Satjipto, 1982, Ilmu Hukum, Alumni, Bandung.

Rahardjo, Satjipto, 2010, Sosiologi Hukum Perkembangan Metode dan Pilihan Masalab), Genta Publishing, Yogyakarta.

Trevino, A. Javier 2008, The Sociology of Law, St. Martins Press, New York.

Ustman, Sabian 2009, Dasar-Dasar Sosiologi Hukum Makna Dialog Antara Hukum \& Masyarakat), Pustaka Pelajar.

Zainuddin Ali, 2007, Sosiologi Hukum, Sinar Grafika, Jakarta.

\section{B. Jurnal}

Dwisvimiar, Inge, 2011, "Keadilan dalam Perspektif Ilmu Hukum", Jurnal Dinamika Hukum, Vol 11. No.3 September 2011. https://doi.org/10.20884/1.jdh.2011.11. 3.179

Ismail, Rizal Ariffin Hairul Nizam, "Konsep Keadilan dalam Teori Kecerdasan Pelbagai Menurut Perspektif Islam”, DP, Vol. 2, 2007.

H.A Saefudin, 2005, "Teori Konflik dan Perubahan Sosial: Sebuah Analisais Kritis", Mediator, Vol. 6, No. 1 Juni 2005.

Sumartono, "Dinamika Perubahan Sosial dalam Teori Konflik", Jurnal Universitas Ekasak.ti.

\section{Internet}


Aksi Main Hakim dan Malam Minggu Terkelam Bagi Pasangan yang Dituduh Berbuat Mesum di Tangerang, http://www.tribunnews.com/metrop olitan/2017/11/15/aksi-main-hakimdan-malamminggu-terkelam-bagipasangan-yang-dituduh-berbuatmesum-di-tangerang, diakses pada tanggal 20 Maret 2018 pukul. 18:00 WIB.

Dampak Psikis Persekusi Penelanjangan, https://tirto.id/dampak-psikispersekusi-penelanjangan-cz8q, diakses pada tanggal 20 Maret 2018 pukul. 18:00 WIB.

Kartika Febriyanti, Pidana Bagi Pelaku Main Hakim Sendiri, http://www.hukumonline. Com / klinikdetail/lt4ec445fc806be/pidana -bagi-pelaku-main-hakim-sendiri diakses pada tanggal 30 Maret 2018 pukul 16:00 WIB.

Mashabi, Sania, "Kronologi dua sejoli di Cikupa diarak warga dan dipaksa mengaku berbuat asusila", https://www.merdeka.com/peristiwa /kronologi-dua-sejoli-di-cikupadiarak-warga-dan-dipaksa-mengakuberbuat-asusila.html, diakses pada tanggal 28 November 2017.

Pak RT Kasus Persekusi Cikupa Menangis, http:/ /jakarta.tribunnews.com/2018/ 03/20/pak-rt-kasus-persekusi-cikupa- menangis-setelah-dengar-tuntutanjaksa diakses pada tanggal 23 Maret 2018 pukul 17:00 WIB.

Persekusi Buruh di Cikupa Didalangi Ketua RT, https://tirto.id/persekusi-buruhdi-cikupa-didalangi-ketua-rt-cz5k, diakses pada tanggal 13 Februari 2018 pukul. 14.33 WIB.

Riyadi, Muhammad Agung, Kasus Penelanjangan di Tangerang, Perlu Kehati-hatian Rumuskan Pasal Kesusilaan, http://www.gresnews.com/berita/hu kum/901511-kasus-penelanjangan-ditangerang-perlu-kehati-hatianrumuskan-pasal-kesusilaan $/ 0 /$, diakses pada 2 Maret 2018 pukul 18:00 WIB.

Taylor, Gloria Safira , "Kronologi Sejoli di Tangerang Ditelanjangi dan Dianiaya Warga",https://www.cnnindonesia.c om/nasional/2017111417251012255 625/kronologisejoliditangerangditelan jangidandkronologisej/, diakses pada tanggal 27 November 2017.

Viral Sepasang Sejoli Yang Diarak dan Ditelanjangi, http://www.tribunnews.com/metrop olitan/2017/11/13/viral-sepasangsejoli-yang-diarak- dan-ditelanjangidi-tangerang-ternyata-bukanpasangan-mesum, diakses pada tanggal 13 Februari 2018 pukul. 14.13 WIB. 